\title{
Empowerment of Integrated Healthcare Center Cadres in Early Detection of Stunting in Toddlers in Kerta Village, Payangan Sub-district, Gianyar Regency
}

\author{
Ni Wayan Rusni ${ }^{1}$, Elmy Saniati ${ }^{2}$, Ni Wayan Erly Sintya Dewi ${ }^{3}$ \\ \{rusrohinidd@gmail.com\} \\ Warmadewa University
}

\begin{abstract}
Stunting is a new problem commonly associated with toddler growth and development. It is found in several regions in Indonesia, especially Payangan Sub-district, Bali. Therefore, according to the Gianyar Regency Government to realize a child-friendly village, stunting cases in toddlers need to be addressed by all relevant parties. Before entering the stage of being able to cope, the ability to detect the case is needed. Efforts to detect possible cases at an early stage in the community is performed by the cadres of Integrated Healthcare Center (Posyandu) and Toddler Family Development (BKB) as the frontline for health services at the banjar level. These cadres need to possess adequate knowledge, skills and ability to detect stunting cases. Therefore, this research aims to improve the ability of cadres through the implementation of training for early stunting case detection. After the training is conducted, the cadres are expected to be able to assist in the faster detection of cases, and provide reports, thereby, leading to a rapid response by relevant parties simultaneously. The training participants' knowledge of stunting were assessed using the pretest and posttest methods. Data analysis showed that the average pretest and posttest values were $2.9 \pm 1.02$ and $7.6 \pm 0.82$, respectively. The results showed that there is a significant increase in the participants' knowledge by $61.84 \%(\mathrm{p}=0.000)$.
\end{abstract}

Keywords: stunting, cadres of integrated healthcare center 


\section{Pendahuluan}

\subsection{Analisis Situasi}

Desa kerta merupakan desa yang berada di wilayah paling utara kecamatan payangan. Desa ini memiliki 8 banjar yang tersebar di wilayah desa kerta. Jarak Desa Kerta ke kota kecamatan yaitu $11 \mathrm{~km}$ dengan waktu tempuh kurang lebih 20 menit. Sebagian besar wilayah Desa Kerta merupakan lahan perkebunan dengan luas 845,09 hektar, seluas 33,55 hektar digunakan sebagai pemukiman dn sekitar 27 hektar, digunakan untuk fasilitas umum seperti pura, setra, jalan, lapangan dan bale banjar. Jumlah penduduk Desa Kerta tahun 2018 adalah 5.580 orang dengan jumlah bervariasi pada masing-masing banjar yang ada di desa Kerta. Sedangkan jumlah balita pada masing-masing banjar yang ada di desa Kerta berkisar 25-50 balita.

Desa Layak Anak (DLA) merupakan salah satu program pemerintah kabupaten Gianyar yang mulai diimplementasikan di kecamatan payangan. Program ini bertujuan untuk meningkatkan kualitas anak-anak sehingga dapat memberikan manfaat bagi seluruh umat manusia kedepannya.1 Merujuk kepada Konvensi Hak Anak (KHA), untuk mewujudkan DLA anak-anak harus mendapatkan haknya sebagai seorang anak yang terdiri dari 5 klaster hak anak yaitu, 1) Hak sipil dan kebebasan, 2) Lingkungan keluarga dan pengasuhan alternatif, 3) Kesehatan dasar dan kesejahteraan, 4) Pendidikan, pemanfaatan waktu luang, dan kegiatan budaya, 5) Perlindungan khusus.

Desa Kerta sebagai bagian dari kecamatan payangan juga mengupayakan hal serupa dalam mencapai tujuan bersama yaitu dengan berusaha menjadikan desa Kerta sebagai desa layak anak. Program ini masih dalam proses pelaksanaan dan tetap memerlukan partisivasi dari berbagai kalangan yang mungkin dapat berperan serta bersama-sama mewujudkan cita-cita menjadikan desa keta sebagai desa layak anak.

Bentuk dari usaha pemenuhan hak anak, berupa hak terkait kesehatan dasar dan kesejahteraan, di Desa Kerta telah terdapat 1 pustu, 1 polindes, 9 posyandu, 2 tempat praktek dokter swasta dan 1 klinik swasta, untuk menunjang pelayanan kesehatan yang memadai bagi anak maupun masyarakat secara umum. Masing-masing banjar dinas telah memiliki posyandu yang aktif dalam kegiatan kesehatan ibu dan bayi serta adanya puskesmas pembantu dan poskesdes yang merupakan tempat pelayanan kesehatan terdekat bagi penduduk Desa Kerta.

Desa Kerta yang terdiri dari 8 banjar, sebenarnya telah memiliki kader posyandu maupun kader BKB (Bina Keluarga Balita) yang tersebar di masing-masing banjar yang ada di Desa Kerta. Jumlah kader posyandu secara keseluruhan di Desa Kerta sebanyak 45 orang dan jumlah kader BKB adalah 64 orang. Secara aktif mereka sebenarnya telah melakukan tugasnya secara rutin seperti melakukan membantu posyandu di masing-masing banjar setiap bulan dan melakukan pembinaan terhadap keluarga yang memiliki balita

\subsection{Masalah Prioritas Mitra}

Profil kesehatan Kabupaten Gianyar Tahun 2016 menunjukkan terdapat sebanyak enam balita yang mengalami gizi buruk, di mana dua diantaranya ditemukan di kecamatan Payangan. Kejadian ini ternyata meningkat menjadi 15 balita pada tahun 2017. Informasi yang diperoleh di UPT Puskesmas Payangan tahun 2018 terdapat 40 balita mengalami gizi kurang, 4 balita mengalami gizi buruk dan satu diantaranya dari penderita gizi kurang tersebut terdapat di des kerta. Data jumlah balita di desa Kerta secara keseluran belum diketahui, namun dari laporan PGC (Post Graduated Study) yang sempat dilakukan di beberapa banjar yang ada di Desa Kerta tercatat terdapat 32 balita di Banjar Saren, 25 balita di Banjar Seming dan di banjar Penyabangan terdapat 41 balita. Ini merupakan jumlah yang diperoleh dari tiga banjar 
dari sembilan banjar yang ada di Desa Kerta. Penilaian pada 25 Buku KMS yang dimiliki oleh setiap balita yang terdapat di Banjar Seming saja, ditemukan 2 balita yang berada di bawah garis hijau untuk grafik kenaikan berat badan dan 6 balita dengan panjang badan per umur berada di bawah 3 SD (- 3SD). Ke- enam balita tersebut termamsuk dalam kategori balita dengan stunting berdasarkan data yang di peroleh. Gambaran keadaan di salah satu banjar yang ada di desa Kerta ini menunjukkan kemungkinan kondisi serupa bisa saja ditemukan di banjar-banjar lainnya yang masih ada di kawasan di desa Kerta.

Kondisi ini merupakan hal yang sebenarnya tidak diharapkan terjadi di Desa Kerta ataupun daerah lainnya, namun kenyataan ditemukannya masalah balita dengan stunting dilapangan hendaknya mendapat tanggapan dan penanganan segera dari pihak-pihak yang terkait agar tidak meluas dan menimbulkan dampak terhadap pertumbuhan dan perkembangan balita.

Keberadaan Kader posyandu maupun kader BKB dengan aktivitas rutin yang telah dilaksanakan sebenarnya sudah sangat mendukung untuk mencapai kesehatan dan kesejahtraan anak yang layak sesuai harapan berdasarkan cita-cita untuk mewujudkan Desa Layak anak. Seiring dengan tujuan tersebut ,maka hendaknya para kader harus dibekali kemampuan untuk bisa melihat dan mendeteksi permasalahan yang mungkin ada di lingkungan tempat mereka bertugas. Selain mampu untuk mendeteksi mereka juga hendaknya dibekali dengan kemampuan apa yang harus dilakukan selanjutnya bila terjadi permasalahan yang tidak di harapkan seperti halnya temuan adanya kasus balita dengan stunting di kawasan tugas mereka.Informasi melalui wawancara yang diperoleh dari kader, diketahui bahwa masih kurangnya dan bahkan dibeberapa banjar lainnya mereka belum pernah mendapatkan informasi tentang stuning. Padahal bila dilihat dari peran dan fungsi para kader, mereka merupakan gardu terdepan dalam mendeteksi masalah kesehatan terutama pada balita dan khususnya tentang terjadinya kasus stunting.

\subsection{Solusi}

Dari uraian masalah prioritas dibidang kesehatan yang dijabarkan pada bab sebelumnya,maka dapat diberikan solusi sebagai berikut:

a. Pemberian materi melalui teknik penyuluhan serta dialog interaktif mengenai stunting mulai dari pengenalan tentang stunting, bagaimana cara mendeteksinya dan bagaimana penanganan awal yang bisa dilakukan sebagai kader, serta bagaimana mencegah terjadinya stunting. Kegiatan ini melibatkan para kader yang berasal dari setiap banjar yang ada di desa Kerta.

b. Memberikan pelatihan bagi kader di desa Kerta cara mendeteksi dini stunting dengan mengadakan pelatihan menggunakan alat-alat ukur yang dapat digunakan untuk mengetahui status kesehatan anak, terutama mengenai status gizi anak dan bagaimana mendiagnosis kasus stunting melalui pengukuran-pen gukuran yang mereka pelajari. Pelatihan menggunakan alat ukur seperti alat timbang anak dan bayi, alat ukur tinggi anak serta bayi, dan membaca kurva pertumbuhan untuk menentukan apakah anak tersebut normal sesui umur atau tidak. Selain itu mereka juga di latih unntuk menentukan kapan seorang balita dikatakan mengalami stunting. 


\section{Metode Pelaksanaan}

\subsection{Tahap Persiapan}

Persiapan dilakukan dengan melakukan koordinasi dan sosialisasi kegiatan meliputi pertemuan koordinasi dengan pihak aparatur Desa Kerta, kecamatan Payangan, kabupaten Gianyar serta perwakilan kader dari masing-masing banjar yang ada di desa Kerta kader mengenai program ini, yang meliputi: tujuan, manfaat, alur kegiatan dan rencana monitoring/evaluasi. Persiapan juga meliputi perencanaan tempat dan sarana dan prasarana yang diperlukan.

\subsection{Tahap Pelaksanaan}

Pelaksanaan kegiatan meliputi:

a Pre test akan dilakukan terlebih dahulu sesaat sebelum penyampaian materi dilaksanakan.

b Pemberian materi dan dialog interaktif mengenai stunting

Pemeberian materi diawali dengan pengenalan mengenai stunting, bahayanya, serta pencegahan yang dapat dilakukan. Selain itu setelah penyampaian materi akan diadakan dialog interaktif antara kader dan penyamapai materi dalam bentuk tanya jawab. Pre test akan dilakukan terlebih dahulu sebelum penyampaian sesaat materi. Materi diberikan oleh tenaga professional yang relevan dan kompeten untuk menyampaikan materi-materi yang akan diberikan. Pemberian materi dilakukan dengan menggunakan media penyuluhan berupa presentasi dengan PPT yang dikombinasi dengan vidio. Selain itu akan dibagikan materi beserta famflet atau brosur mengenai stunting.

c Pelatihan kader dalam mengukur dan deteksi stunting

Pelatihan akan di awali dengan peragaan secara langsung oleh ahlinya secara bersama sama, kemudian di bagia dalam kelompok-kelompok kecil yang merupakan perwakilan dari masing masing banjar. Pelatihan dilakukan lebih intensif di masing-masing kelompok kecil tersebut dengan didampingi oleh para pendamping yang telah di persiapkan. Garis besar konten pelatihan meliputi, pengenalan alat-alat yang dipergunakan untuk pengukuran dan deteksi stunting, cara melakukan pengukuran serta menginterpretasikan hasil pengukuran yang diperoleh. Dari interpretasi tersebut akhirnya kader diharapkan mampu untuk menyimpulkan hasil pengukuran secara keseluruhan. Pada akhir sesi kegiatan akan dilakukan kembali post test untuk melihat ada tidaknya peningkatan pengetahuan dari semua materi dan pelatihan yang telah diberikan.

\section{Hasil Dan Pembahasan}

Pelaksanaan program diawali dengan pembukaan acara oleh PLT kepala desa Kerta dan kemudian langsung dilanjutkan dengan pengisian materi oleh narasumber tentang stunting. Sebelum materi diberikan telah dilaksanakan pre test terlebih dahulu untuk mengetahui tingkat pengetahuan awal dari peserta pelatihan. Pada beberapa saat sebelum dilakukan penyampaian materi, para peserta juga diberikan beberapa pertanyaan lisan oleh narasumber dengan tujuan yang sama. Pemberian materi dilakukan selama kurang lebih satu jam dengan diselingi juga pemutaran vidio terkait materi yang disampaikan. Setelah pemberian materi, diskusi dan pelatihan selesai dilaksanakan, kembali dilaksanakan post test untuk mengetahui seberapa jauh peserta dapat menyerap materi dan pelatihan yang telah diberikan. 
Keseluruhan kader yang mengikuti pelatihan semuanya berjenis kelamin perempuan. Gambaran variasi tingkat pedidikan mereka adalah dominan merupakan lulusan sekolah menengah atas (SMA) sebanyak 40\%, masing-masing 25\% terdiri dari lulusan sekolah dasar (SD) dan sekolah menengah pertama (SMP), serta sisanya 10\% merupakan tamatan sarjana. Rata-rata kader yang mengikuti pelatihan memiliki pekerjaan sebagian besar sebagai petani, wiraswasta dan sebagai ibu rumah tangga.

Hasil penilaian tingkat pengetahuan peserta mengenai stunting dinilai dengan menggunakan metode pretest dan postest. Analisa data menunjukkan rata-rata nilai pretest adalah 2,9 $\pm 1,02$ dan rata-rata nilai postest sebesar 7,6 $\pm 0,82$. Berdasarkan hasil pretest dan posttest tersebut, dapat dilihat adanya peningkatan pengetahuan yang signifikan pada peserta pelatihan sebesar $61,84 \%(\mathrm{p}=0.000)$

Pemberian materi dilanjutkan dengan diskusi dan tanya jawab. Dari hasil observasi peserta tampak antusias mendengarkan penyampaian materi yang diberikan. Hal ini tampak tidak hanya pada terfokusnya perhatian peserta saat materi disampaikan, tetapi juga tampak dari banyaknya pertanyaan yang muncul dari peserta pelatihan saat dilaksanakan sesi diskusi. Terdapat lebih dari 4 orang yang mengajukan pertanyaan terkait materi pelatihan yang telah diberikan. Pertanyaan yang diajukan oleh peserta diberikan tanggapan langsung oleh narasumber. Partispasi aktif dari peserta pelatihan telah mencapai target sesuai dengan indikator capaian dalam program ini.

\section{Kesimpulan}

Kegiatan yang dilaksanakan mendapatkan respon yang baik dari pihak terkait serta para kader yang memang menjadi sasaran dalam kegiatan ini. peningkatan pengetahuan serta ketrampilan yang diperoleh mampu meningkatkan kapasitas mereka sebagai kader dalam melaksankan tugas dengan lebih baik.

\section{References}

[1] DEPKES. 2016. Profil Kesehatan Kabupaten Gianyar tahun 2016. Dinas Kesehatan Kbupaten Gianyar

[2] DEPKES. 2017. Profil Kesehatan Kabupaten Gianyar tahun 2016. Dinas Kesehatan Kabupaten Gianyar

[3] Kementerian Kesehatan RI. 2014. Peraturan Menteri Kesehatan Republik Indonesia Nomor 28 Tahun 2014 Tentang Pedoman Pelaksanaan Jaminan Kesehatan Nasional. (http://www.depkes.go.id/resources/download/general/PMK\%20No.\%2028\%20ttg\%20Pedoman \%20Pelaksanaan\%20Program\%20JKN.pdf, diakses 27 Januari 2019)

[4] Kementrian Republik Indonesia. 2016. Gizi. Profil Kesehatan Indonesia Tahun 2015. Pp; 144159

[5] RISKESDAS. 2013. Status Gizi anak Balita. Badan Penelitian dan Pengembangan Kementrian RI Tahun 2013. Pp; 2019-215

[6] Tanziha I, Faletehan SF, Iskandar M. 2015. Modul Pengembangan Desa/Kelurahan Layak Anak (DLA). (http://pkga.ipb.ac.id/wp-content/uploads/2018/05/MODUL-KELURAHAN DESALAYAK-ANAK-.pdf, diakses: 26 Januari 2019)

[7] UPT Kesmas Payangan. 2018.Status Gizi. Rekapan laporan Pustu 